\title{
Radiation overdose: the utility of ct scanning in self poisoning
}

\author{
G Sondh $^{1 *}$, S Noble $^{2}$, Rl Docking ${ }^{2}$, P Doherty ${ }^{2}$, A Davidson $^{2}$, A Mackay $^{2}$ \\ From ESICM LIVES 2015 \\ Berlin, Germany. 3-7 October 2015
}

\section{Introduction}

The UK has one of the highest deliberate self-poisoning overdoses within Europe [1]. The majority of them have a short length of stay with a low mortality. Patients commonly present with a reduced GCS, triggering the order for a CT scan. This is generally despite the absence of lateralising neurology, leading to multiple scans, especially for recurrent overdoses, often providing little or no clinical benefit and at a cost of $£ 88$ per scan [2].

\section{Methods}

This was a retrospective cohort study using data from the Scottish Intensive Care Society database and radiology archive software. Six thousand three hundred and thirtythree patients were available and 332 patients matched the parameters we set. These parameters were:

a) Any ICU diagnosis that equals drug overdose/misuse

b) Any ICU diagnosis that equals drug toxicity

c) Any ICU diagnosis that equals self poisoning

The one hundred most recent patients within this group were then selected.

We collected demographic data, details of overdose and CT scan reports for these 100 patients using the hospital clinical information systems.

\section{Results}

All patients admitted to the Victoria Infirmary ICU with drug overdoses between 13 January 2009 and 4 July 2014 were reviewed. One hundred patients were identified. The mean age was 38 years. Fifty-six patients were male and 44 were female.

The median (IQR) length of stay within ICU was 2 (1-3) [range (1-20)] days. Median (IQR) APACHE II score $(\mathrm{n}=82)$ was $17(17-21)$ [range (4-40)]. Five patients $(5 \%)$ died while in ICU.

${ }^{1}$ University of Glasgow, Medical School, Glasgow, United Kingdom Full list of author information is available at the end of the article
Antidepressants were the most commonly abused drug with 32(18\%) cases reported. The next major group was alcohol with 29(17\%) cases and then benzodiazepine with 22 (13\%) cases. The majority of overdoses were mixed substances. $43 \%$ of patients had CT scans taken, only 9 ( $20 \%$ of the 43 scanned) of these patients showed signs of head trauma and none of these cases had pathology on their CT scan. 31/34(91\%) of the non-trauma cases had negative findings. The remaining $3 / 34$ (9\%) had positive CT findings and all of these significantly changed their management. Two of these patients died. Pre intubation GCS was recorded in $63 \%$ of patients. The remaining $37 \%$ had no GCS information available. The median and mode GCS were both 3 .

\section{Discussion}

Our initial hypothesis was that CT brain scanning was superfluous in the context of drug overdose and represented a defensive medical practice. The results of this audit have highlighted that very occasionally CT scanning results in discovering pathology that significantly affects subsequent management and disposal. We feel that we should continue with our current practice and that no reduction in CT scanning is indicated.

No external funding and no competing interests declared.

\section{Authors' details}

${ }^{1}$ University of Glasgow, Medical School, Glasgow, United Kingdom. Victoria Infirmary, Glasgow, United Kingdom.

Published: 1 October 2015

\section{References}

1. Camidge DR, Wood RJ, Bateman DN: The epidemiology of self-poisoning in the UK. 2003, 56(6):613-619, Dec.

2. [http://www.isdscotland.org/Health-Topics/Finance/Costs/Detailed-Tables/ Radiology.asp], Accessed 01/10/14. 
doi:10.1186/2197-425X-3-S1-A611

Cite this article as: Sondh et al: Radiation overdose: the utility of ct scanning in self poisoning. Intensive Care Medicine Experimental 20153 (Suppl 1):A611.

\section{Submit your manuscript to a SpringerOpen ${ }^{\circ}$ journal and benefit from:}

- Convenient online submission

- Rigorous peer review

- Immediate publication on acceptance

- Open access: articles freely available online

- High visibility within the field

- Retaining the copyright to your article

Submit your next manuscript at $\gg$ springeropen.com 